\title{
On-line Electrogeneration of Copper-Peptide Complexes in Microspray Mass Spectrometry
}

\author{
Michel Prudent and Hubert H. Girault \\ Laboratoire d'Electrochimie Physique et Analytique, Ecole Polytechnique Fédérale de Lausanne, \\ Lausanne, Switzerland
}

\begin{abstract}
The interaction of copper ions with peptides was investigated by electrospray mass spectrometry. Two electrospray micro-emitters were compared, the first one with a platinum electrode using a copper(II) electrolyte solution containing a peptide sample, and the second one with a sacrificial copper anode in a water/methanol solution containing only a peptide (i.e., angiotensin III, bradykinin, or Leu-enkephalin). The former yielded mainly $\mathrm{Cu}^{2+}$ complexes either with histidine residues or with the peptide backbone $\left(\mathrm{Cu}^{+}\right.$complexes can be also formed due to gas-phase reactions), whereas the latter can generate a mixture of both $\mathrm{Cu}^{+}$and $\mathrm{Cu}^{2+}$ aqueous complexes that yield different complexation patterns. This study shows that electrospray emitters with soluble copper anodes enable the study of $\mathrm{Cu}(\mathrm{I})$-peptide complexes in solution. (J Am Soc Mass Spectrom 2008, 19, 560-568) (C) 2008 American Society for Mass Spectrometry
\end{abstract}

$\mathrm{T}$ ransition-metal ions and especially copper are essential elements in all living systems [1, 2], but can also activate pathological disorders [3-6]. Cuprous ions $\left(\mathrm{Cu}^{+}\right)$are considered soft metal ions whereas cupric ions $\left(\mathrm{Cu}^{2+}\right)$ are intermediate. In vivo, the anchor sites for $\mathrm{Cu}^{+}$include the thiol moieties of cysteines and those for $\mathrm{Cu}^{2+}$ include the imidazole residues of histidines $[1,7,8]$. In the gas phase, the binding sites of $\mathrm{Cu}^{2+}$ are quite identical [9] to those observed in solution whereas arginine becomes the preferred anchorage for $\mathrm{Cu}^{+}[10,11]$. Nevertheless, all these interactions are condition-dependent and other groups on a peptide can also be involved in the coordination of copper $[12,13]$. Metal binding sites can be deduced by several techniques such as X-ray or nuclear magnetic resonance. Of course, mass spectrometry (MS) has been used for a long time to study inorganic complexes, especially since the introduction of soft ionization techniques such as electrospray ionization (ESI) and matrix-assisted laser desorption/ionization (MALDI), which are especially adapted to study bioinorganic complexes [14].

Copper complexes have been studied by different MS techniques. The traditional method is to mix a copper salt solution with the sample or by direct production of cations from metallic copper. For example, $\mathrm{Cu}^{+}$ions have been generated in the gas phase by direct ionization of the metal in fast atom bombardment and in MALDI [15-17]. In aqueous solutions, $\mathrm{Cu}^{+}$is unstable, and specific sample preparations are required (anaerobic conditions, adequate solvent). When copper

Address reprint requests to Professor Hubert H. Girault, Laboratoire d'Electrochimie Physique et Analytique, Ecole Polytechnique Fédérale de Lausanne, Station 6, 1015 Lausanne, Switzerland. E-mail: hubert.girault@ epfl.ch salts are used, $\mathrm{Cu}^{+}$ions are produced either by specific preparation of a copper(I) salt $[18,19]$ or by gas-phase reactions using a copper(II) salt. In ESI-MS studies, $\mathrm{Cu}^{+}$ ions are produced by reduction of $\mathrm{Cu}^{2+}$ during the ionization process [20-22] even in positive ionization mode. Lavanant et al. have observed the reduction of $\mathrm{Cu}^{2+}$ complexes by electron capture as well as by oxidation of the surrounding molecules such as methanol [22]. Gianelli et al. have reported the effect of the solvent on $\mathrm{Cu}^{2+}$ reduction and correlated the production of $\mathrm{Cu}^{+}$with the ionization energy of alcohols [23]. $\mathrm{Cu}^{2+}$ reduction can be favored by increasing the nozzleskimmer voltages or the source voltage. Schröder et al. have also observed this phenomenon by increasing the cone voltage [24].

An alternative method to produce metal ions is the direct oxidation of the metallic electrode tip [25-27]. Indeed, in positive ionization mode, the anode used to provide the spray current is the locus of an oxidation process that can generate reactive species that can in turn undergo further reactions, for example for the on-line tagging of peptides [28-33]. We have demonstrated that a sacrificial metal electrode coupled to microchip-ESI-MS can be used for the study of the metal complexes [34]. Moreover, sacrificial copper electrode leads to the formation either of $\mathrm{Cu}^{2+}$ or of $\mathrm{Cu}^{+}$ aqueous complexes depending on the ligands present in solution, as illustrated by using 8-hydroxyquinoline and bathocuproine [35].

In the present work, we investigate copper-peptide complexes formed in solution using a copper electrode. Peptides containing or not containing specific anchor sites for $\mathrm{Cu}^{2+}$ or $\mathrm{Cu}^{+}$were sprayed to study the complexation sites. In addition, the influence of these cations on peptides fragmentation was studied. 


\section{Experimental}

\section{Chemicals}

Human angiotensin III (angIII, RVYIHPF, $M=931.1$ $\mathrm{g} / \mathrm{mol}$ ), angiotensin I/II(1-7) (angI/II, DRVYIHP, $M=$ $899.0 \mathrm{~g} / \mathrm{mol}),\left(\mathrm{Sar}^{1}\right)$ angiotensin I/II(1-7) amide (angI/ $\mathrm{II}_{-} \mathrm{NH}_{2}$, SarRVYIHP-NH $\left.{ }_{2}, \quad M=854.0 \mathrm{~g} / \mathrm{mol}\right)$, Leuenkephalin (enke, YGGFL, $M=555.6 \mathrm{~g} / \mathrm{mol}$ ), were bought from Bachem (Bubendorf, Switzerland) and bradykinin (RPPGFSPFR, $M=1060.2 \mathrm{~g} / \mathrm{mol}$ ) from Sigma (St Louis, MO). Cupric chloride dihydrate $\left(\mathrm{CuCl}_{2} \cdot 2 \mathrm{H}_{2} \mathrm{O}\right)$ was from Acros Organics (Geel, Belgium) and methanol from Riedel-de-Haën (Seelze, Germany). Deionized water $(18.2 \mathrm{M} \Omega \cdot \mathrm{cm})$ was prepared using a Milli-Q system from Millipore (Bedford, MA). The peptides were used as received and diluted at a final concentration of $50 \mu \mathrm{M}$ in $50 / 50$ (vol/vol) $\mathrm{MeOH} /$ $\mathrm{H}_{2} \mathrm{O}$. All the solutions were prepared fresh daily.

\section{MS Setup and Microspray Interface}

Metal ion on-line complexation was carried out using a microspray interface described previously [34, 35]. In brief, it consists of a single microchannel (45 $\mu \mathrm{m} \times$ $120 \mu \mathrm{m} \times 1 \mathrm{~cm}$ ) polyimide microchip developed by DiagnoSwiss SA (Monthey, Switzerland) [36, 37]. A reservoir of polycarbonate $(\varnothing=6.5 \mathrm{~mm}, h=5 \mathrm{~mm})$ was glued at the inlet of the microchannel. The sample was loaded $(V=100 \mu \mathrm{L})$ in the reservoir in which a metallic electrode was immersed. This electrode was made of platinum wire (blank and copper(II) salt experiments) or of copper plate $\left(S=30 \mathrm{~mm}^{2}\right)$. Both electrodes were sanded and rinsed with methanol before each experiment.

An LCQ DUO ion trap mass spectrometer (Thermo, San Jose, CA) was used in positive ion mode. The heated capillary was kept at $200{ }^{\circ} \mathrm{C}$ (except for the experiments with bradykinin). The commercial ESI interface was removed and the microchip was mounted on a plate fixed on the probe slide adapter of the mass spectrometer. After the MS power supply onset $(U=$ $3.5 \mathrm{kV}$ ) the chip was moved closer to the entrance of the MS. The current was set between 30 and $80 \mathrm{nA}$ by adjusting the distance between the microspray outlet and the entrance of the MS, and monitored by a nano-ammeter. The ion optics parameters were kept constant for each peptide studied. The flow rate was estimated at $300 \mathrm{~nL} / \mathrm{min}$ according to Morier et al. [38]. The MS fragments were assigned based on the calculation of a web-based software, MS-Products from UCSF (http://prospector.ucsf.edu/prospector / 4.0.8/html/msprod.htm).

\section{Isotopic Distribution Calculation}

The isotopes of copper are ${ }^{63} \mathrm{Cu}$ and ${ }^{65} \mathrm{Cu}$ with a natural abundance of $69.17 \%$ and $30.83 \%$, respectively, and a mass of 62.93 and $64.93 \mathrm{u}$. Thus, a copper complex shows a typical isotopic distribution that can be altered by the different oxidation states of copper. Considering a mono-charged peptide, ${ }^{63} \mathrm{Cu}^{+}$or ${ }^{63} \mathrm{Cu}^{2+}$ binding releases one or two protons, respectively, yielding a theoretical mass difference (with the native peak) of 61.9 or 60.9 Da.

With the aim to distinguish the proportion of the different oxidation states of copper in the peptide complexes, theoretical and experimental isotopic distributions were compared. Theoretical isotopes were obtained by the software CS ChemDraw Pro (CambridgeSoft Corporation, Cambridge, MA). According to the isotope of $\left[\mathrm{M}+\mathrm{Cu}^{\mathrm{I}}\right]^{+}$and $\left[\mathrm{M}+\mathrm{Cu}^{\mathrm{II}}-\mathrm{H}\right]^{+}$or others, a weighted average of the relative abundance of each isotope was calculated.

$$
I_{i, \text { al }}=\alpha \cdot I_{i, \mathrm{Cu}(\mathrm{II})}+(1-\alpha) \cdot I_{i, \mathrm{Cu}(\mathrm{I})}
$$

where $I_{i, c a l}$ represents the calculated relative abundance of the isotope $i, I_{i, C u(I I)}$ the theoretical relative abundance of the isotope $i$ where only $\mathrm{Cu}^{2+}$ is linked, $I_{i, C u(I)}$ the theoretical relative abundance of the isotope $i$ where only $\mathrm{Cu}^{+}$ is linked, and $\alpha$ is a variable comprised between 0 and 1. The optimum ratio $\alpha$ was obtained with minimizing the difference $(r)$ between experiments and calculations.

$$
r=\sum_{i=1}^{n}\left(I_{\mathrm{i}, \mathrm{cal}}-I_{i, \exp }\right)^{2}
$$

where $I_{i, \text { exp }}$ stands for the relative abundance obtained by mass spectrometry. Thus, $\alpha$ gives the ratio $\mathrm{Cu}^{2+} /$ $\mathrm{Cu}^{+}$coordinated to a peptide. The experimental error on the relative abundance of isotopes induced by the data processing is lower than $2 \%$. This error was calculated for ions of known isotopic composition, such as $[\mathrm{M}+\mathrm{H}]^{+}$for angiotensin III. $\alpha$-Values were averaged on several experiments for the same experimental conditions and the standard deviations were precised on the given values.

\section{Results and Discussion}

\section{Copper-Angiotensin III Complexes}

Copper(II) and copper(I) ions that can be produced in solution by a sacrificial copper electrode present a good affinity for histidine and arginine, respectively. Therefore, a histidine- and arginine-containing peptide, namely angiotensin III (RVYIHPF), has been chosen to study the relative complexation properties of the two oxidation states. Experiments were first carried out classically with a Pt electrode for reference (data not shown). The mono and doubly charged peptides were observed at $m / z=931.5 \mathrm{Th}$ and at $m / z=466.3 \mathrm{Th}$, respectively, and no fragment ions could be detected. When the copper electrode is used described above, copper ions are electrogenerated by anodic dissolution of the electrode and $\mathrm{Cu}^{n+}$-angIII complexes are formed as clearly shown in Figure 1a where two copper complexes can be observed. The mono-copper complex 

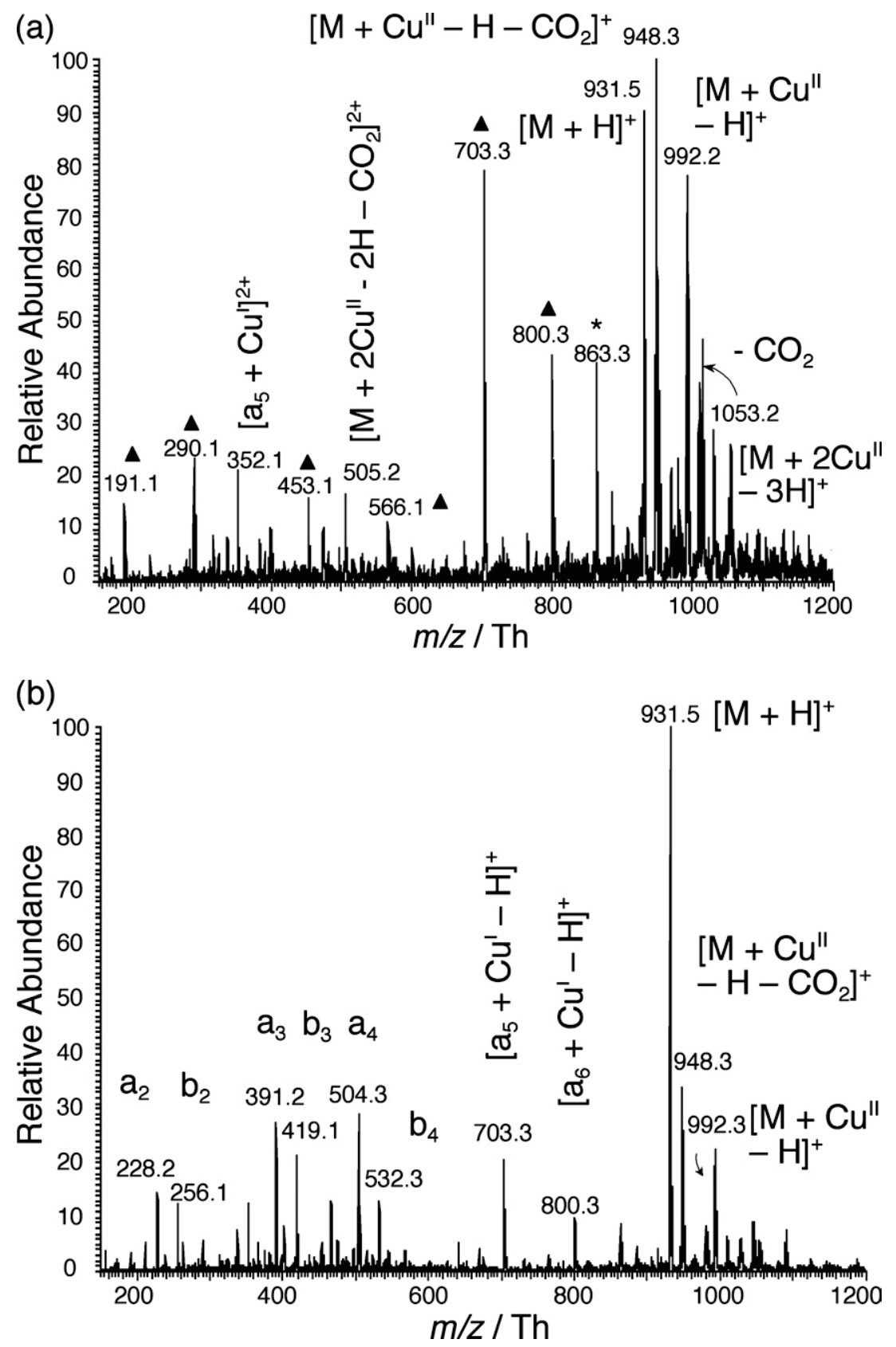

Figure 1. Mass spectra of angiotensin III (RVYIHPF, $50 \mu \mathrm{M}$ ) in 50/50 (vol/vol) $\mathrm{MeOH} / \mathrm{H}_{2} \mathrm{O}$ obtained with (a) a Cu electrode, $\mathrm{t}=59 \mathrm{~min}$, (same pattern was observed after $25 \mathrm{~min}$ ) and (b) a Pt electrode in presence of $\mathrm{CuCl}_{2}$ at $400 \mu \mathrm{M}$; (filled triangle) $\mathrm{a}_{n}$-ions bound to $\mathrm{Cu}^{+}$; (asterisk) $\mathrm{x}_{6}$ bound to $\mathrm{Cu}^{+} . \mathrm{Cu}^{2+}$ ions generated from either copper electrode or copper(II) salt induce the fragmentation of angiotensin III. Cu electrode clearly gives the access to $\mathrm{Cu}^{+}$complexes.

(copper:peptide, 1:1) at $\mathrm{m} / \mathrm{z}=992.2 \mathrm{Th}$, previously reported [34, 39], appeared straightaway whilst the bimetallic complex (2:1) at $\mathrm{m} / \mathrm{z}=1053.2$ Th appeared after few minutes of electrolysis. Focusing on the isotopic distribution of the mono-copper complex, four peaks can mainly be observed where the relative abundances show in fact an overlap of two oxidation states. To determine the ratio between $\mathrm{Cu}^{2+}$ and $\mathrm{Cu}^{+}$, the theoretical isotopic distribution has been calculated (see Table 1). In comparison with the experiment, these data clearly show that the mono-copper complexes are constituted by $76 \% \pm 3 \%$ of $\mathrm{Cu}^{2+}$ under these experimental conditions. This can be due either to the binding of copper ions on different sites, $\left(\mathrm{RVYIH}\left(\mathrm{Cu}^{2+}\right) \mathrm{PF}\right.$ or $\left.\mathrm{R}\left(\mathrm{Cu}^{+}\right) \mathrm{VYIHPF}\right)$, or to a mixed population of $\mathrm{Cu}^{2+} /$ $\mathrm{Cu}^{+}$on a given site, (e.g., $\left.\mathrm{RVYIH}\left(\mathrm{Cu}^{2+/+}\right) \mathrm{PF}\right)$, induced by an in situ reduction of $\mathrm{Cu}^{2+}$-histidine complexes in the gas phase [20, 22-24, 35]. As the copper electrode is able to produce either $\mathrm{Cu}^{2+}$ or $\mathrm{Cu}^{+}$aqueous ions, $\mathrm{Cu}^{2+}$-histidine and/or $\mathrm{Cu}^{+}$-arginine complexes can in 
Table 1. Relative abundance of the isotopes of $\mathrm{Cu}^{n+}$-angiotensin III complexes

\begin{tabular}{ccccc}
\hline & \multicolumn{4}{c}{$l / \%$} \\
\cline { 2 - 5 } m/z/Th & $\begin{array}{c}\mathrm{Cu}^{n+} \text {-anglll } \\
\text { experimental }\end{array}$ & $\begin{array}{c}\mathrm{Cu}^{2+} \text {-anglll } \\
\text { theoretical }^{\text {a }}\end{array}$ & $\begin{array}{c}\mathrm{Cu}^{+} \text {-anglll } \\
\text { theoretical }^{\text {a }}\end{array}$ & $\begin{array}{c}\mathrm{Cu}^{n+} \text {-anglll } \\
\text { calculated }^{\text {b }}\end{array}$ \\
\hline \hline 992.2 & $100 \pm 0$ & 100 & 0 & $100 \pm 4$ \\
993.2 & $89 \pm 5$ & 55 & 100 & $87 \pm 4$ \\
994.3 & $76 \pm 6$ & 61 & 55 & $78 \pm 4$ \\
995.3 & $45 \pm 3$ & 28 & 61 & $47 \pm 4$ \\
996.2 & $20 \pm 3$ & 7 & 28 & $16 \pm 4$ \\
997.2 & $7 \pm 1$ & 1 & 8 & $4 \pm 4$ \\
\hline
\end{tabular}

a Obtained from the software CS ChemDraw Pro.

${ }^{\mathrm{b} C a l c u l a t e d}$ according to eq 1 with $\alpha=0.76 \pm 0.03$.

principle be concomitantly formed. The peak pattern observed for the bimetallic complex at $\mathrm{m} / \mathrm{z}=1053.2 \mathrm{Th}$ also shows the presence of both $\mathrm{Cu}^{2+}$ and $\mathrm{Cu}^{+}$species (data not shown).

In contrast, the experiments performed with a platinum electrode (with the same MS parameters) in the presence of $\mathrm{CuCl}_{2}$ added to the peptide solution revealed only a mono-copper complex at $m / z=992.3 \mathrm{Th}$ (Figure 1b) with a lower conversion rate. Moreover, the copper(II) salt concentration required (400 $\mu \mathrm{M})$ had to be in excess compared with that of the peptide $(50 \mu \mathrm{M})$ to achieve an equivalent result to that obtained with the copper electrode $\left(5 \mu \mathrm{M} \mathrm{Cu}^{2+}\right.$ electrogenerated in $30 \mathrm{~min}$ according to the Faraday's law). These results suggest a difference of reactivity between copper ions added as a salt or electrogenerated. In the first case, the counterions, namely chloride, can lead to the formation of different chloride complexes, thereby decreasing the free ion concentration whereas the electrogenerated copper ions can only be complexed by water or methanol. Then, these cations are more reactive towards angiotensin III, yielding a higher conversion rate. In addition, reactions at the surface of the electrode could also contribute to this phenomenon.

\section{Copper-Angiotensin III Complexes Fragmentation}

The binding of copper ions to angIII was found to induce its fragmentation (Figure 1). The degradation induced by electrogenerated copper ions presents all the a-type fragments linked to one copper ion (Figure 1a, Scheme 1a). All these fragments contain an arginine residue, which is able to coordinate $\mathrm{Cu}^{+}$. In comparison, $\mathrm{CuCl}_{2}$ also induced a fragmentation, but only histidinecontaining fragments complexed with $\mathrm{Cu}^{+}$are observed (Figure 1b, Scheme $1 b$ ). The fragments $a_{n, n}<5$ are not complexed and no copper ions were found anchored to arginine. These $\mathrm{Cu}^{+}$-histidine-containing fragments must result from $\mathrm{Cu}^{2+}$ ions initially bound to histidine but reduced in the gas phase during the fragmentation. The fragmentation patterns (not induced by MS/MS experiments) show that the mono-copper complex discussed above is a mixture of two complexes, one with $\mathrm{Cu}^{2+}$ bound to histidine and one with $\mathrm{Cu}^{+}$bound to arginine.

When $\mathrm{Cu}^{2+}$ binds to the histidine of angIII, the C-terminus is involved in the formation of a tetracoordinated complex including the oxygen of the carboxylate [7]. Figure 1a shows, for the native peak tagged, a loss of 43.9 Da corresponding to the loss of the carboxylate group of the C-terminus in which the oxidation state of $\mathrm{Cu}^{2+}$ is maintained, as observed by several studies $[39,40]$. Indeed, focusing on the isotopic distributions of the mono-copper complex peaks and of the decarboxylated one, the calculations gave $76 \% \pm 3 \%$ (see Table 1) and $96 \% \pm 3 \%$ (data not shown) of $\mathrm{Cu}^{2+}$, respectively. This suggests that the loss of $\mathrm{CO}_{2}$ is induced by the presence of $\mathrm{Cu}^{2+}$ and not its reduction. However, the other fragments are complexed with $\mathrm{Cu}^{+}$ (the isotopic distribution of the $\mathrm{a}_{n}$-ions bound to copper shows $100 \%$ of $\mathrm{Cu}^{+}$). These complexed $\mathrm{a}_{n}$-ions can be explained as follows. After the loss of $\mathrm{CO}_{2}$, an electrontransfer reducing $\mathrm{Cu}^{2+}$ to $\mathrm{Cu}^{+}$oxidizes the peptide and the observed complexes are coordinated with $\mathrm{Cu}^{+}$. When the fragmentation reaches the histidine, copper unbinds from the peptide and stays on the departing histidine (experiments performed with angiotensin II (DRVYIHPF) showed a $\left(\mathrm{a}_{6} \mathrm{y}_{3}\right)$ fragment linked to $\mathrm{Cu}^{+}$, i.e., the immonium ion of histidine, corroborating this particular loss with $\mathrm{Cu}^{+}$ions). In addition, the fragments $\mathrm{a}_{n, n<5}$ (Figure 1a) are bound to $\mathrm{Cu}^{+}$. Therefore, it seems that the complexed ions $a_{5}$ and $a_{6}$ come from $a$ monometallic complex and that the $\mathrm{a}_{n, n}<5$ fragments come from a bimetallic peptide after release of a $\mathrm{Cu}^{+}{ }_{-}$

(a)

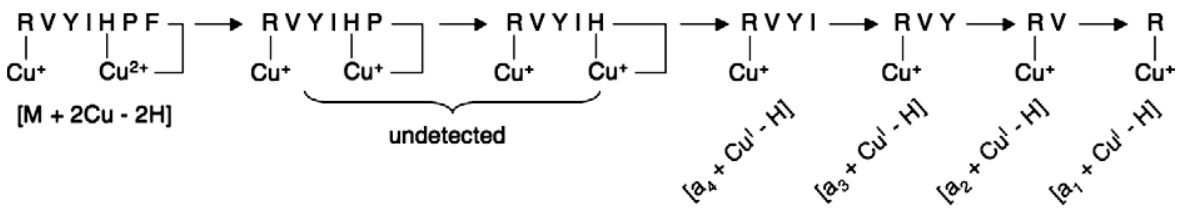

(b)

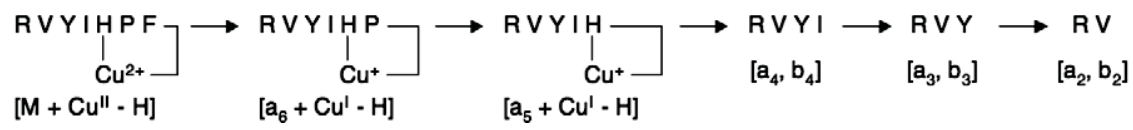

Scheme 1. Fragmentation of angiotensin III induced by copper ions. Experiments ran with (a) a $\mathrm{Cu}$ electrode and (b) a Pt electrode in presence of $\mathrm{CuCl}_{2}$. 
histidine complex (Scheme 1a). This fragmentation is also coherent with the experiment run with the platinum electrode in presence of $\mathrm{CuCl}_{2}$, where the histidine-free fragments are not linked to copper (Figure 1b, Scheme 1b). In these peaks, only the histidine-containing fragments are complexed (with $\mathrm{Cu}^{+}$) and all the fragments are present. All these experiments suggest that the initiation of the fragmentation is induced by $\mathrm{Cu}^{2+}$.

To understand the influence of the C-terminus carboxylate on the fragmentation process, angiotensin I/II(1-7) and (Sar ${ }^{1}$ )angiotensin I/II(1-7) amide were sprayed with a copper electrode (Figure 2). A quick view of these spectra clearly exhibits the difference. The first peptide, DRVYIHP, enables the binding of two $\mathrm{Cu}^{2+}$ ions by the presence of two anchor sites, i.e., aspartic acid and histidine (Figure 2a). Consequently, these sites undergo the formation of a bimetallic complex at $m / z=1021.1$ Th (the monometallic complex being at $m / z=960.2 \mathrm{Th}$ ). As with angIII, the decarboxylation occurs and then $\mathrm{Cu}^{2+}$ can oxidize the peptide. All $\left[\mathrm{a}_{n, n>5}+\mathrm{Cu}^{\mathrm{I}}-\mathrm{H}\right]^{+}$fragments and immonium ions of arginine bound to copper $\left(\left[\left(\mathrm{a}_{2} \mathrm{y}_{6}\right)+\mathrm{Cu}^{\mathrm{I}}-\mathrm{H}\right]^{+}\right)$are
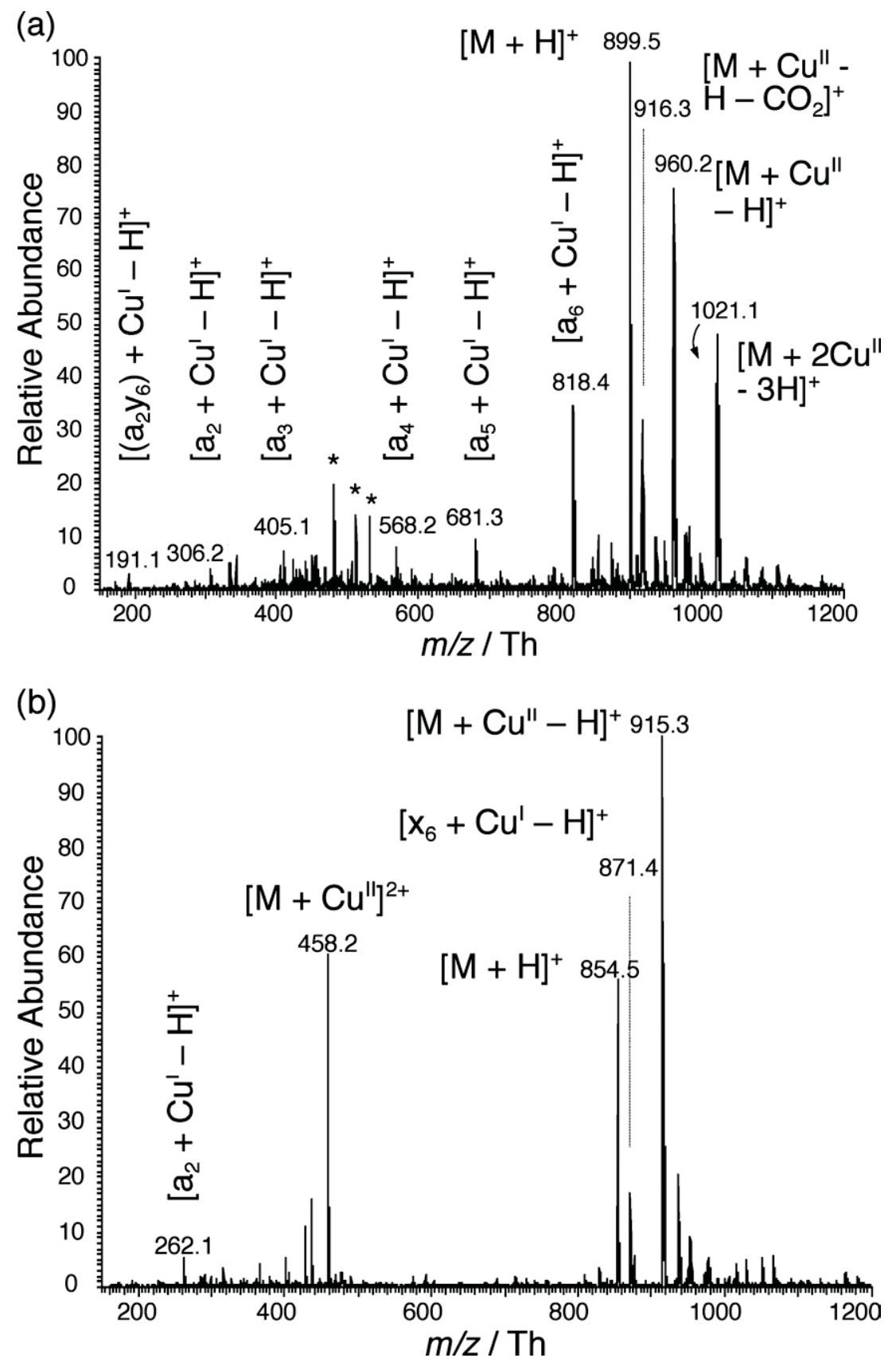

Figure 2. Mass spectra of (a) angiotensin I/II (DRVYIHP, $50 \mu \mathrm{M}), \mathrm{t}=1 \mathrm{~h} 23$, and (b) (Sar $\left.{ }^{1}\right)$ angiotensin I/II amide (SarRVYIHP-NH $\mathrm{N}_{2}, 50 \mu \mathrm{M}$ ), $\mathrm{t}=1 \mathrm{~h} 21$, in $50 / 50$ (vol/vol) $\mathrm{MeOH} / \mathrm{H}_{2} \mathrm{O}$ performed with a $\mathrm{Cu}$ electrode; (asterisk) doubly charged species. The amidation of the $\mathrm{C}$-terminus stops the fragmentation induced by copper ions. 
also observed. In contrast, the peptide with the modified C-terminus (SarRVYIHP-NH ${ }_{2}$ ) does not show a clear fragmentation (Figure $2 \mathrm{~b}$ ). There is only one adduct of $\mathrm{Cu}^{2+}$ at $m / z=915.3 \mathrm{Th}$, which loses 43.9 Da corresponding to the loss of the fragment $\mathrm{a}_{1}$, the immonium moiety from $N$-methylglycine (Sar group).

These mass spectra confirm the influence of the C-terminus on the fragmentation pathway. The replacement of aspartic acid by $N$-methylglycine prevents the addition of a copper ion at the N-terminus but does not change the binding to the arginine. When the carboxylate group is unmodified, the histidine-containing fragment $\left[\mathrm{a}_{6}+\mathrm{Cu}^{\mathrm{I}}-\mathrm{H}\right]^{+}$is intense and many others fragments, including $\left[\left(\mathrm{a}_{2} \mathrm{y}_{6}\right)+\mathrm{Cu}^{\mathrm{I}}-\mathrm{H}\right]^{+}$corresponding to a copper ion linked to arginine, are observed. These results are consistent with the interpretation made for angiotensin III. When the amidated peptide is studied, only a mono-copper complex and a fragment $\left[\mathrm{a}_{2}+\mathrm{Cu}^{\mathrm{I}}-\mathrm{H}\right]^{+}$are present. No histidine-containing fragments are observed. Copper ions bind to arginine when the carboxylate group is not free and probably with the participation of nitrogen from the amide bound. This adduct being a $\mathrm{Cu}^{2+}$ complex, a binding between the guanidine and the imidazole residues is not excluded. The loss of $43.9 \mathrm{Da}$ corresponds to the fragment $\mathrm{a}_{1}$ and the peak at $m / z=871.4 \mathrm{Th}$ is $\left[\mathrm{x}_{6}+\right.$ $\left.\mathrm{Cu}^{\mathrm{I}}-\mathrm{H}\right]^{+}$. The amidation of the C-terminus stops the fragmentation due to the formation of a $\mathrm{Cu}^{2+}$-histidine complex, as reported by $\mathrm{Hu}$ and Loo [39].

\section{Copper-Bradykinin Complexes}

Histidine-free peptides were then used to test the production of $\mathrm{Cu}^{+}$-peptide complexes from a sacrificial copper electrode. Bradykinin (RPPGFSPFR) contains two arginines able to bind theoretically two $\mathrm{Cu}^{+}$ions. Again, this peptide was sprayed with a copper electrode and with a platinum electrode in presence of $\mathrm{CuCl}_{2}$. The most intense peak was the mono charged peptide at $m / z=1060.6 \mathrm{Th}$. With both methods, the addition of one $\mathrm{Cu}^{+}$ion was observed at $\mathrm{m} / z=1122.4$ Th even if the proportion of $\mathrm{Cu}^{+}$was less important when using a copper(II) salt (roughly $65 \%$ versus $90 \%$ of $\mathrm{Cu}^{+}$with the copper electrode). According to the peptide structure, the formation of $\mathrm{Cu}^{+}$complexes should be enhanced and the spray condition could facilitate the $\mathrm{Cu}^{2+}$ reduction in the gas phase. The comparison between the use of a copper electrode and a copper(II) salt was not straightforward. Decreasing the heated capillary temperature has been found in this case to enhance the formation of doubly charged peptides and also the formation of $\mathrm{Cu}^{2+}$ complexes, probably helped by a lower desolvation rate. Thus, the temperature of the heated capillary was fixed at $100{ }^{\circ} \mathrm{C}$ instead of $200{ }^{\circ} \mathrm{C}$. The relative abundance of the doubly charged bradykinin $(\mathrm{m} / \mathrm{z}=530.9 \mathrm{Th})$ and that of mono charged at $m / z=1060.6$ Th were $100 \%$ and $20 \%$, respectively. First, bradykinin was sprayed with a copper electrode and the oxidation produced mainly a doubly charged $\mathrm{Cu}^{+}$-bradykinin complex at $\mathrm{m} / \mathrm{z}=$ 561.7 Th. However, after $15 \mathrm{~min}$ the proportion changed and a $\mathrm{Cu}^{2+}$ complex was observed to reach $\sim 60 \%$ and $80 \%$ of $\mathrm{Cu}^{2+}$ after 30 and $60 \mathrm{~min}$ of electrospray, respectively. According to the soft ionization, the mass spectrum of bradykinin obtained with a platinum electrode in presence of $\mathrm{CuCl}_{2}$ shows the formation of a $\mathrm{Cu}^{2+}$-bradykinin complex at $\mathrm{m} / z=561.1 \mathrm{Th}$. Indeed, under these conditions, this copper adduct was only formed by $\mathrm{Cu}^{2+}$. Bradykinin has two anchor sites for $\mathrm{Cu}^{+}$, via arginine $[10,11]$, but also can complex $\mathrm{Cu}^{2+}$ via the amide group of the peptide backbone or different part of the amino acids side chain $[12,13]$.

Copper-bradykinin complexes did not fragment like the copper-angiotensin III complexes. Collision-induced dissociation (CID) was thus required. Table 2 summarizes the fragment ions coming from tandem mass spectrometry (at 33\% of collision energy) of [M+ $\left.\mathrm{Cu}^{\mathrm{II}}\right]^{2+}$ and $\left[\mathrm{M}+\mathrm{H}+\mathrm{Cu}^{\mathrm{I}}\right]^{2+}$. The CID spectrum patterns and several peaks are different. For the $\mathrm{Cu}^{2+}$ complexes, the most intense peaks are the immonium ions of arginine bound to $\mathrm{Cu}^{+}$(either from the $\mathrm{N}$ terminus or the $\mathrm{C}$-terminus after a $\mathrm{CO}_{2}$ loss) and several fragments bound to $\mathrm{Cu}^{2+}$. The presence of $\mathrm{Cu}^{2+}$ induces the loss of $\mathrm{CO}_{2}$ (44 Da), of formaldehyde coming from the serine side chain $\left(\mathrm{CH}_{2} \mathrm{O}, 30 \mathrm{Da}\right)$ [41, 42], of water and the loss of a part of guanidine moiety from arginine $(\mathrm{HN}=\mathrm{C}=\mathrm{NH}, 42 \mathrm{Da})[41,43]$. Several a- and b-ions $\left(\mathrm{a}_{8}, \mathrm{a}_{6}, \mathrm{a}_{5}, \mathrm{~b}_{4}\right)$ are linked to $\mathrm{Cu}^{+}$(including the immonium ion of arginine), suggesting the N-terminus arginine is the anchor site after $\mathrm{Cu}^{2+}$ reduction. Intense $\mathrm{x}$ - and $\mathrm{y}$-ions $\left(\mathrm{x}_{8}, \mathrm{x}_{7}, \mathrm{y}_{7}\right)$ are mainly linked to $\mathrm{Cu}^{2+}$. In addition, internal fragments corresponding to PPGF and FSP or SPF are also complexed with $\mathrm{Cu}^{2+}$. As a result, copper(II) seems fixed in the middle of the structure and copper(I), probably coming from $\mathrm{Cu}^{2+}$ reduction, is coordinated to one of the arginine. As for the CID spectrum of $\left[\mathrm{M}+\mathrm{H}+\mathrm{Cu}^{\mathrm{I}}\right]^{2+}$, the fragments are coordinated with $\mathrm{Cu}^{+}$. The loss of the serine side chain, water, and part of the guanidine represents the most abundant species and the decarboxylation is not observed (phenomenon also observed with angIII where $\mathrm{CO}_{2}$ loss was related to $\mathrm{Cu}^{2+}$ ). Several a- and b-ions support the formation of $\mathrm{Cu}^{+}$complexes at the $\mathrm{N}$-terminus and the immonium ion of arginine (less abundant compared with the fragmentation of $[\mathrm{M}+$ $\left.\mathrm{Cu}^{\mathrm{II}}\right]^{2+}$ ) corroborates the binding between copper(I) and arginine. Taking into account the absence of $\mathrm{CO}_{2}$ loss and the relative weak abundance of $\left[\mathrm{Im} \mathrm{R}+\mathrm{Cu}^{\mathrm{I}}\right]^{+}$ $(27.2 \%)$ compared with the fragmentation of the $\mathrm{Cu}^{2+}$ complex $(100 \%)$, it seems that $\mathrm{Cu}^{+}$(produced at the copper electrode) is linked to the $\mathrm{N}$-terminus arginine; and that $\left[\mathrm{Im} \mathrm{R}+\mathrm{Cu}^{\mathrm{I}}\right]^{+}$produced from $\mathrm{CuCl}_{2}$ stems from the $\mathrm{C}$-terminus as well as the $\mathrm{N}$-terminus arginine. These CID spectrum patterns emphasize the difference in $\mathrm{Cu}^{2+}$ and $\mathrm{Cu}^{+}$binding site on bradykinin. In the absence of histidine, the oxidation of the copper electrode produced copper(I) ions able to bind at the arginine. On the other hand, copper(II) ions coming 


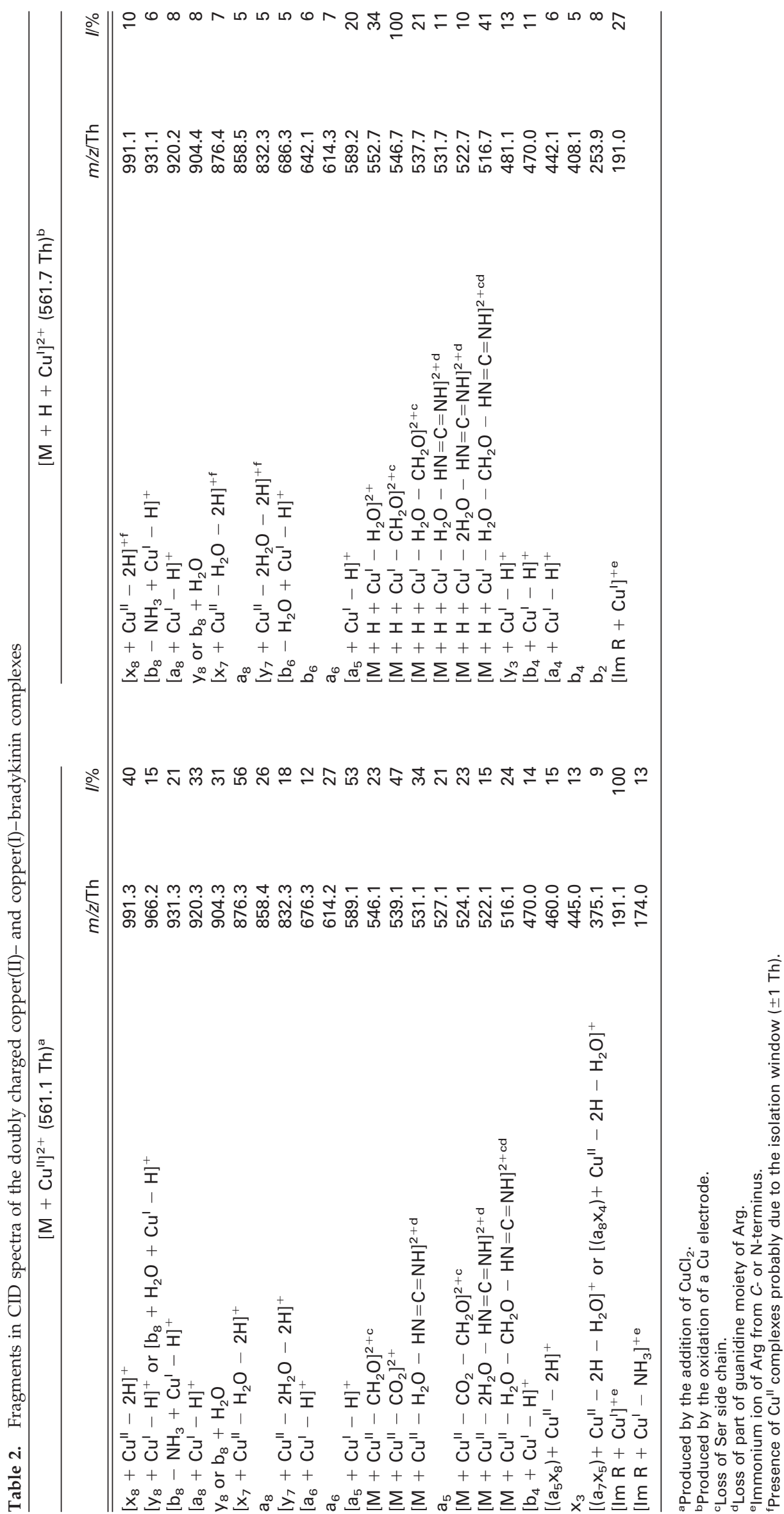


from the salt are fixed in the middle of the structure but are also able to produce $\mathrm{Cu}^{+}$-arginine complexes after reduction of $\mathrm{Cu}^{2+}$-bradykinin complexes during CID experiment. These fragments suggest a rearrangement in the copper coordination after the reduction of $\mathrm{Cu}^{2+}$.

\section{Copper-Enkephalin Complexes}

Leu-enkephalin (YGGFL) was finally used as a histidine and arginine free sequence (Table 3). In the absence of coordination sites, the metallic ions will anchor to the amide groups of the peptide backbone via nitrogen [12]. The mass spectra obtained with a Pt electrode show the presence of the mono charged peptides at $m / z=556.2$ Th, the fragments $b_{2}, b_{3}, a_{4}$, and $b_{4}$, and also the formation of noncovalent dimers $[44,45]$ and trimers at $m / z=1111.2 \mathrm{Th}$ and 1665.9 Th. The use of a copper electrode instead of a platinum wire produced two copper adducts at $m / z=618.1 \mathrm{Th}$ and $m / z=679.9$ Th. The 1:1 complex was formed after a few seconds, whereas the 2:1 complex appeared after a few minutes. The mono-copper complex corresponds to a mixture of $\left[\mathrm{M}+\mathrm{Cu}^{\mathrm{I}}\right]^{+}(m / z=618.1 \mathrm{Th})$ and $\left[\mathrm{M}+\mathrm{Cu}^{\mathrm{II}}-\mathrm{H}\right]^{+}$ $(m / z=617.1 \mathrm{Th})$ in equivalent quantity according to the isotopic distribution. The dimer is mainly complexed with one $\mathrm{Cu}^{2+}(\mathrm{m} / \mathrm{z}=1172.1 \mathrm{Th})$ and two $\mathrm{Cu}^{+}$ions $(m / z=1235.1 \mathrm{Th})$. As observed above, the copper ions induce some fragmentations. The losses of $\mathrm{CO}_{2}$ and then the radical propyl and the tyrosine side chain were observed at $m / z=573.1 \mathrm{Th}, m / z=530.1 \mathrm{Th}$ and $m / z=510.0 \mathrm{Th}$, respectively. These two last fragments are formed of $\mathrm{Cu}^{+}$and come from the reduction of $\mathrm{Cu}^{2+}$, as explained by Tabet and coworkers $[40,46]$. Indeed, the fragmentation of $\left[\mathrm{M}+\mathrm{Cu}^{\mathrm{I}}\right]^{+}$ cannot give these fragments. Finally, MS/MS experiments (data not shown) performed on the peaks $m / z=618.1 \mathrm{Th}$ and $m / z=530.0 \mathrm{Th}$ confirmed the binding site of $\mathrm{Cu}^{+}$in the middle of the sequence, i.e., on Gly. Obviously, the coordination is achieved by the peptidic bond.

When a copper(II) salt is used a platinum electrode, the results are almost identical and the difference stems mainly from the ratio between copper ions and Leuenkephalin. The first adduct $(m / z=616.9 \mathrm{Th})$ is mainly formed by $\mathrm{Cu}^{2+}$ (roughly $80 \%$ ) and the bimetallic complex is $\left[\mathrm{M}+2 \mathrm{Cu}^{\mathrm{I}}-\mathrm{H}\right]^{+}$at $m / z=680.0 \mathrm{Th}$. As for the fragments, the same pattern as before has been observed. However, few differences in the ratio must be pointed out. The isotopic distribution around $\mathrm{m} / \mathrm{z}=$ $510.0 \mathrm{Th}\left(\left[\mathrm{M}+\mathrm{Cu}^{\mathrm{I}}-\mathrm{H}-\cdot \mathrm{C}_{7} \mathrm{H}_{7} \mathrm{O}\right]^{+}\right)$revealed the presence of a $\mathrm{Cu}^{2+}$ complex at $m / z=511.0 \mathrm{Th}([\mathrm{M}+$ $\left.\mathrm{Cu}^{\mathrm{II}}-\mathrm{H}-\mathrm{C}_{7} \mathrm{H}_{6} \mathrm{O}\right]^{+}$, not observed with the copper electrode). This fragment corresponds to the loss of 105.9 Da. As described by Bossée et al. [47], this molecule is obtained by the loss of the tyrosine moiety without $\mathrm{Cu}^{2+}$ reduction. Finally, the binding site of $\mathrm{Cu}^{2+}$ remains the same as before (according to CID experiments) even if the fragmentation of $\left[\mathrm{a}_{4}+\mathrm{Cu}^{\mathrm{I}}-\right.$ $\mathrm{H}^{+}$shows a copper adduct on YG structure. Furthermore, MS/MS experiments carried out on the bimetallic complex at $m / z=680.0$ Th highlighted the binding of two $\mathrm{Cu}^{+}$ions on the GF part of Leu-enkephalin.

The experiment performed with the sacrificial copper electrode produced more $\mathrm{Cu}^{+}$ions than the one carried out with a copper(II) salt. Approximately $40 \%$ of $\mathrm{Cu}^{+}$were produced by the anodic dissolution of the copper electrode. The fragments (those induced by the metastable ions formed by addition of copper ions, see difference in Table 3) are most abundant when using $\mathrm{CuCl}_{2}$. These fragments mainly stem from the reduction of $\mathrm{Cu}^{2+}$ complexes in $\mathrm{Cu}^{+}$and are explainable by the higher presence of mono-copper(II) complex. Indeed, the fragments $\left[\mathrm{M}+\mathrm{Cu}^{\mathrm{I}}-\mathrm{H}-\mathrm{CO}_{2}-\mathrm{C}_{3} \mathrm{H}_{7}\right]^{+}$and $\left[\mathrm{M}+\mathrm{Cu}^{\mathrm{I}}-\mathrm{H}-\cdot \mathrm{C}_{7} \mathrm{H}_{7} \mathrm{O}\right]^{+}$can only come from $\mathrm{Cu}^{2+}$ reduction. These experiments are equivalent although the copper electrode produces more $\mathrm{Cu}^{+}$ions. Moreover, the

Table 3. Peaks observed when spraying Leu-enkephalin $(50 \mu \mathrm{M})$ with different electrodes or in presence of $\mathrm{CuCl}_{2}(50 \mu \mathrm{M})$

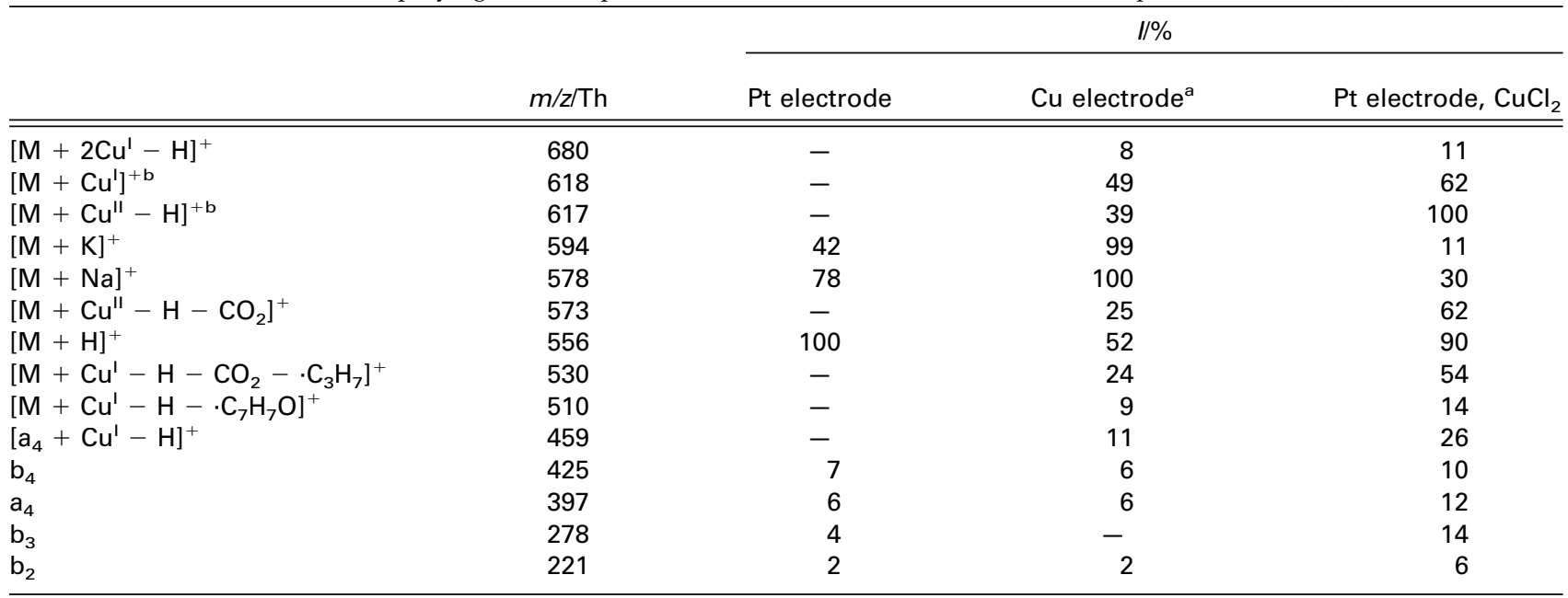

aObtained after 30 min of experiment.

$\mathrm{b} /$ is influenced by the isotopic distributions (see text for details). 
$\mathrm{Cu}^{+}$and $\mathrm{Cu}^{2+}$ anchor sites are the same in this sequence in absence of particular copper binding sites.

\section{Conclusions}

As reported previously for small molecules, sacrificial copper electrode leads to the formation of either copper(I) or copper(II) aqueous complexes depending on the ligands present in solution. The present work highlights the behavior of a soluble copper anode during the analysis of cysteine-free peptides in positive ionization mode. Indeed, copper cations can oxidize the thiol moiety of cysteine to form disulfide bridges. Further experiments will be performed in such direction and with more complex samples.

\section{Acknowledgments}

The authors thank The Fonds National Suisse pour la Recherche Scientifique for financial support through the project "Analytical tools for fast phosphoproteome analysis" (grant no 200020113413/1). The authors also acknowledge Dr. Christophe Roussel for discussions.

\section{References}

1. Roat-Malone, R. M. Bioinorganic Chemistry, 1st ed.; John Wiley and Sons: Hoboken, 2002

2. Liang, X.; Campopiano, D. J.; Sadler, P. J. Metals in Membranes. Chem. Soc. Rev. 2007, 36, 968-992.

3. Strozyk, D.; Bush, A. I. In Neurodegenerative Diseases and Metal Ions, Vol. I; Sigel, A.; Sigel, H.; Sigel, R. K. O., Eds., Wiley: Chichester, England, 2006, pp 1-7.

4. Bush, A. I. The Metallobiology of Alzheimer's Disease. Trends Neurosci. 2003, 26, 207-214

5. Bush, A. I.; Masters, C. L.; Tanzi, R. E. Copper, $\beta$-Amyloid, and Alzheimer's Disease: Tapping a Sensitive Connection. Proc. Natl. Acad. Sci. U.S.A. 2003, 100, 11193-11194.

6. Waggoner, D. J.; Bartnikas, T. B.; Gitlin, J. D. The Role of Copper in Neurodegenerative Disease. Neurobiol. Dis. 1999, 6, 221-230

7. Kozlowski, H.; Bal, W.; Dyba, M.; Kowalik-Jankowska, T. Specific Structure-Stability Relations in Metallopeptides. Coord. Chem. Rev. 1999, 184, 319-346.

8. Deschamps, P.; Kulkarni, P. P.; Gautam-Basak, M.; Sarkar, B. The Saga of Copper(II)-L-Histidine. Coord. Chem. Rev. 2005, 249, 895-909.

9. Lavanant, H.; Hecquet, E.; Hoppilliard, Y. Complexes of L-Histidine with $\mathrm{Fe}^{2+}, \mathrm{Co}^{2+}, \mathrm{Ni}^{2+}, \mathrm{Cu}^{2+}, \mathrm{Zn}^{2+}$ Studied by Electrospray Ionization Mass Spectrometry. Int. J. Mass Spectrom. 1999, 187, 11-23.

10. Cerda, B. A.; Wesdemiotis, C. The Relative Copper(I) Ion Affinities of Amino Acids in the Gas Phase. J. Am. Chem. Soc. 1995, 117, 9734-9739.

11. Bluhm, B. K.; Shields, S. J.; Bayse, C. A.; Hall, M. B.; Russell, D. H. Determination of Copper Binding Sites in Peptides Containing Basic Residues: A Combined Experimental and Theoretical Study. Int. J. Mass Spectrom. 2001, 204, 31-46.

12. Sigel, H.; Martin, R. B. Coordinating Properties of the Amide Bond Stability and Structure of Metal-Ion Complexes of Peptides and Related Ligands. Chem. Rev. 1982, 82, 385-426.

13. Hu, P. F.; Sorensen, C.; Gross, M. L. Influences of Peptide Side-Chains on the Metal-Ion Binding-Site in Metal Ion-Cationized PeptidesParticipation of Aromatic Rings in Metal Chelation. J. Am. Soc. Mass Spectrom. 1995, 6, 1079-1085.

14. Henderson, W.; McIndoe, J. S. Mass Spectrometry of Inorganic, Coordination and Organometallic Compounds: Tools-Techniques-Tips, 1st ed; John Wiley and Sons: Chichester, 2005

15. Freas, R. B.; Campana, J. E. Reactions of Sputtered Copper Cluster Ions. J. Am. Chem. Soc. 1985, 107, 6202-6204.

16. Lei, Q. P.; Amster, I. J. The Reactions of Ground State $\mathrm{Cu}^{+}$and $\mathrm{Fe}^{+}$with the 20 Common Amino Acids. J. Am. Soc. Mass Spectrom. 1996, 7, $722-730$

17. Shields, S. J.; Bluhm, B. K.; Russell, D. H. Novel Method for $[\mathrm{M}+\mathrm{Cu}]^{+}$ Ion Formation by Matrix-Assisted Laser Desorption Ionization. Int. J. Mass Spectrom. 1999, 183, 185-195.

18. Remy, H. Treatise on Inorganic Chemistry: Elsevier: Amsterdam, 1956.

19. Merrifield, M. E.; Huang, Z. Y.; Kille, P.; Stillman, M. J. Copper Speciation in the $\alpha$ and $\beta$ Domains of Recombinant Human Metallothionein by Electrospray Ionization Mass Spectrometry. J. Inorg. Biochem. 2002, 88, 153-172.
20. Gatlin, C. L.; Turecek, F.; Vaisar, T. Copper(II) Amino Acid Complexes in the Gas Phase. J. Am. Chem. Soc. 1995, 117, 3637-3638.

21. Lavanant, H.; Hoppilliard, Y. Fragmentation of Arginine- and LysineContaining Dipeptides Cationized by $\mathrm{Cu}^{+}$and $\mathrm{Cu}^{2+}$. Eur. Mass Spectrom. 1999, 5, 41-50

22. Lavanant, H.; Virelizier, H.; Hoppilliard, Y. Reduction of Copper(II) Complexes by Electron Capture in an Electrospray Ionization Source. J. Am. Soc. Mass Spectrom. 1998, 9, 1217-1221.

23. Gianelli, L.; Amendola, V.; Fabbrizzi, L.; Pallavicini, P.; Mellerio, G. G. Investigation of Reduction of $\mathrm{Cu}(\mathrm{II})$ Complexes in Positive-Ion Mode Electrospray Mass Spectrometry. Rapid Commun. Mass Spectrom. 2001, $15,2347-2353$.

24. Schröder, D.; Holthausen, M. C.; Schwarz, H. Radical-Like Activation of Alkanes by the Ligated Copper Oxide Cation (Phenanthroline) $\mathrm{CuO}^{+}$. J. Phys. Chem. B 2004, 108, 14407-14416.

25. Blades, A. T.; Ikonomou, M. G.; Kebarle, P. Mechanism of Electrospray Mass Spectrometry. Electrospray as an Electrolysis Cell. Anal. Chem. 1991, 63, 2109-2114.

26. Van Berkel, G. J.; Kertesz, V. Redox Buffering in an Electrospray Ion Source Using a Copper Capillary Emitter. J. Mass Spectrom. 2001, 36, 1125-1132.

27. Van Berkel, G. J.; Asano, K. G.; Schnier, P. D. Electrochemical Processes in a Wire-in-a-Capillary Bulk-Loaded, Nano-Electrospray Emitter. J. Am. Soc. Mass Spectrom. 2001, 12, 853-862.

28. Van Berkel, G. J.; Kertesz, V. Using the Electrochemistry of the Electrospray Ion Source. Anal. Chem. 2007, 79, 5510-5520.

29. Rohner, T. C.; Lion, N.; Girault, H. H. Electrochemical and Theoretical Aspects of Electrospray Ionization. Phys. Chem. Chem. Phys. 2004, 6, 3056-3068.

30. Zhang, T. Y.; Palii, S. P.; Eyler, J. R.; Brajter-Toth, A. Enhancement of Ionization Efficiency by Electrochemical Reaction Products in On-Line Electrochemistry/Electrospray Ionization Fourier Transform Ion Cyclotron Resonance Mass Spectrometry. Anal. Chem. 2002, 74, 1097-1103.

31. Van Berkel, G. J.; Asano, K. G.; Granger, M. C. Controlling Analyte Electrochemistry in an Electrospray Ion Source with a Three-Electrode Emitter Cell. Anal. Chem. 2004, 76, 1493-1499.

32. Roussel, C.; Dayon, L.; Lion, N.; Rohner, T. C.; Josserand, J.; Rossier, J. S.; Jensen, H.; Girault, H. H. Generation of Mass Tags by the Inherent Electrochemistry of Electrospray for Protein Mass Spectrometry. J. Am. Soc. Mass Spectrom. 2004, 15, 1767-1779.

33. Dayon, L.; Roussel, C.; Prudent, M.; Lion, N.; Girault, H. H. On-Line Counting of Cysteine Residues in Peptides During Electrospray Ionization by Electrogenerated Tags and Their Application to Protein Identification. Electrophoresis 2005, 26, 238-247.

34. Rohner, T. C.; Girault, H. H. Study of Peptide On-Line Complexation with Transition-Metal Ions Generated from Sacrificial Electrodes in Thin-Chip Polymer Microsprays. Rapid Commun. Mass Spectrom. 2005, 19, 1183-1190.

35. Prudent, M.; Roussel, C.; Girault, H. H. Electrochemical Generation of $\mathrm{Cu}(\mathrm{I})$ Complexes in Aqueous Solutions Studied by On-Line Mass Spectrometry. Electrochem. Commun. 2007, 9, 2067-2074.

36. Rossier, J. S.; Vollet, C.; Carnal, A.; Lagger, G.; Gobry, V.; Girault, H. H.; Michel, P.; Reymond, F. Plasma Etched Polymer Microelectrochemical Systems. Lab. Chip 2002, 2, 145-150.

37. Gobry, V.; Van Oostrum, J.; Martinelli, M.; Rohner, T. C.; Reymond, F.; Rossier, J. S.; Girault, H. H. Microfabricated Polymer Injector for Direct Mass Spectrometry Coupling. Proteomics 2002, 2, 405-412.

38. Morier, P.; Vollet, C.; Michel, P. E.; Reymond, F.; Rossier, I. S. GravityInduced Convective Flow in Microfluidic Systems: Electrochemical Characterization and Application to Enzyme-Linked Immunosorbent Assay Tests. Electrophoresis 2004, 25, 3761-3768.

39. Hu, P. F.; Loo, J. A. Gas-Phase Coordination Properties of $\mathrm{Zn}^{2+}, \mathrm{Cu}^{2+}$ $\mathrm{Ni}^{2+}$, and $\mathrm{Co}^{2+}$ with Histidine-Containing Peptides. J. Am. Chem. Soc. 1995, 117, 11314-11319.

40. Bossée, A.; Fournier, F.; Tasseau, O.; Bellier, B.; Tabet, J. C. Electrospray Mass Spectrometric Study of Anionic Complexes of Enkephalins with $\mathrm{Cu}(\mathrm{II})$ : Regioselective Distinction of Leu/Ile at the C-terminus Induced by Metal Reduction. Rapid Commun. Mass Spectrom. 2003, 17, 1229-1239.

41. Shields, S. J.; Bluhm, B. K.; Russell, D. H. Fragmentation Chemistry of $[\mathrm{M}+\mathrm{Cu}]^{+}$Peptide Ions Containing an N-terminal Arginine. J. Am. Soc. Mass Spectrom. 2000, 11, 626-638.

42. Reiter, A.; Teesch, L. M.; Zhao, H.; Adams, J. Gas-Phase Fragmentations of Anionic Complexes of Serine- and Threonine-Containing Peptides. Int. J. Mass Spectrom. Ion Processes 1993, 127, 17-26.

43. Deery, M. J.; Summerfield, S. G.; Buzy, A.; Jennings, K. R. A Mechanism for the Loss of $60 \mathrm{u}$ from Peptides Containing an Arginine Residue at the C-terminus. J. Am. Soc. Mass Spectrom. 1997, 8, 253-261.

44. Cai, X. M.; Dass, C. Structural Characterization of Methionine and Leucine Enkephalins by Hydrogen/Deuterium Exchange and Electrospray Ionization Tandem Mass Spectrometry. Rapid Commun. Mass Spectrom. 2005, 19, 1-8.

45. Mastropaolo, D.; Camerman, A.; Ma, L. Y. Y.; Camerman, N. CrystalStructure of an Extended-Conformation Leucine-Enkephalin Dimer Monohydrate. Life Sci. 1987, 40, 1995-1999.

46. Boutin, M.; Bich, C.; Afonso, C.; Fournier, F.; Tabet, J. C. Negative-Charge Driven Fragmentations for Evidencing Zwitterionic Forms from Doubly Charged Coppered Peptides. J. Mass Spectrom. 2007, 42, 25-35.

47. Bossée, A.; Afonso, C.; Fournier, F.; Tasseau, O.; Pepe, C.; Bellier, B. Tabet, J. C. Anionic Copper Complex Fragmentations from Enkephalins under Low-Energy Collision-Induced Dissociation in an Ion Trap Mass Spectrometer. J. Mass Spectrom. 2004, 39, 903-912. 